\title{
Pengaruh Metode Penyeimbangan Kelas Terhadap Tingkat Akurasi Analisis Sentimen pada Tweets Berbahasa Indonesia
}

\author{
http://dx.doi.org/10.28932/jutisi.v6i2.2743 \\ Ivan Nathaniel Husada ${ }^{\# 1}$, Hapnes Toba ${ }^{凶 * 2}$ \\ * Program Studi Magister Ilmu Komputer, Fakultas Teknologi Informasi \\ Universitas Kristen Maranatha \\ Jl. Prof. drg. Surya Sumantri No.65 Bandung \\ 11879008 emaranatha. ac.id \\ 2hapnestobadit.maranatha.edu
}

\begin{abstract}
Nowadays internet access is getting easier to get. Because of the ease of access to the internet, almost all internet users have social media. Social media is widely used by users to call out their opinions or even to make complaints about a matter and also discuss a topic with other social media users. From many existing social media, one that is popularly used for that activity is Twitter. Sentiment analysis on Twitter has become possible because of the activities of these Twitter users. In this research, the authors explore sentiment analysis with bag-of-words and Term Frequency Inverse Document Frequency (TF-IDF) features extraction based on tweets from Indonesian Twitter users. The data obtained is in imbalanced condition, so that it requires a method to overcome them. The method for overcoming imbalanced dataset uses resampling approach which combine over and under sampling strategies. The results of sentiment analysis accuracies with Naïve Bayes and neural networks before and after input data resampling are also compared. Naïve Bayes methods that will be used are Multinomial Naïve Bayes and Complement Naïve Bayes, while the Neural Network architecture that will be used as a comparison are Recurrent Neural Networks, Long Short-Term Memory, Gated Recurrent Units, Convolutional Neural Networks, and a combination of Convolutional Neural Networks and Long Short-Term Memory. Our experiments show the following harmonic scores (F1) of the sentiment analysis models: the Multinomial Naïve Bayes F1 score is 55.48, Complement Naïve Bayes is 51.33, Recurrent Neural Network is 75.70, Long Short-Term Memory is 78.36, Gated Recurrent Unit is 77.96, Convolutional Neural Network is 76.12, and finally the combination of Convolutional Neural Networks and Long Short-Term Memory achieves 81.14.
\end{abstract}

Keywords - Imbalanced Data; Naïve Bayes; Neural Network; Sentiment Analysis; Twitter.

\section{Pendahuluan}

Pada jaman sekarang ini masyarakat sudah dapat dengan mudah mendapatkan akses internet. Hal itu terjadi karena semakin banyaknya layanan wifi di tempat-tempat publik maupun semakin murahnya tarif internet yang disediakan oleh provider. Hal itu juga menyebabkan sebagian besar masyarakat memiliki akun media sosialnya masing-masing. Selain itu media sosial yang dapat digunakan oleh masyarakat pun semakin banyak jenisnya sehingga masyarakat dapat memilih untuk memakai media sosial mana yang dianggap lebih nyaman. Media sosial yang banyak digunakan masyarakat untuk menyerukan opininya atau pun melakukan protes terhadap suatu hal dan bertukar opini dengan pengguna media sosial lainnya terhadap suatu topik adalah media sosial Twitter. Karena hal tersebut maka analisis sentimen akan dapat dimanfaatkan untuk mencari tahu seperti apakah kecenderungan opini masyarakat yang diwakili oleh pengguna Twitter terhadap suatu topik tertentu.

Pada penelitian kali ini akan dilakukan percobaan melakukan analisis sentimen berbahasa Indonesia dengan kelas yang tidak seimbang pada dataset yang diambil dari media sosial Twitter. Dataset tersebut akan dipilih sehingga hanya data yang sesuai dengan konteks yang diinginkan yang berada dalam dataset. Setelah dipilih dataset akan dinormalisasi dan diberi label secara manual, oleh dua orang anotator, untuk menentukan nilai sentimen yang ada dari setiap tweets-nya. Algoritma klasifikasi yang dipakai pada penelitian analisis sentimen ini adalah algoritma Multinomial Nä̈ve Bayes dan Complement Nä̈ve Bayes dengan ekstraksi fitur Bag-of-Words dan TF-IDF. Selain itu juga akan digunakan beberapa arsitektur Neural Network seperti Recurrent Neural Network, Long Short-Term Memory, Gated Recurrent Unit, Convolutional Neural Network, dan kombinasi dari Convolutional Neural Network dan Long Short-Term Memory dengan ekstraksi fitur menggunakan Word Embedding Vector FastText sebagai pembanding. 
Hal yang akan menjadi tujuan utama dalam penelitian adalah bagaimanakah perbandingan performa antara model dengan algoritma klasifikasi Nä̈ve Bayes dengan arsitektur Neural Network. Hal khusus yang menjadi salah satu titik pengamatan dalam penelitian terkait dengan masalah ketidakseimbangan data pada kelas dataset sehingga dibutuhkan metode untuk menyeimbangkan kelas dataset tersebut.

Oleh karena itu pada penelitian ini juga akan dibandingkan efek metode menyeimbangkan data tersebut dengan hasil analisis sentimen sebelum data diseimbangkan. Dengan demikian akan dapat diketahui efek dari metode penyeimbangan data antara algoritma klasifikasi Nä̈ve Bayes dan beberapa arsitektur Neural Network.

\section{KAJIAN LITERATUR}

Pada bagian ini akan dibahas beberapa teori yang berhubungan dengan penelitian yang dilakukan.

\section{A. Twitter}

Media sosial Twitter adalah media sosial microblogging yang memungkinkan penggunanya untuk mengirim atau membaca tweets yang dibatasi hingga 280 karakter sehingga dianggap pengguna Twitter akan dapat menyampaikan maksud dan tujuan dengan singkat, padat, dan jelas. Sehingga banyak pengguna Twitter menggunakan akun Twitter-nya masing-masing untuk mengutarakan pendapatnya terhadap suatu topik tertentu ataupun bertukar opini dengan pengguna Twitter lainnya [1]. Selain itu Twitter dipilih pada penelitian ini karena data pada Twitter lebih mudah untuk diakses dan terbuka untuk publik. Karena hal tersebut maka analisis sentimen akan dapat dimanfaatkan untuk mencari tahu seperti apakah kecenderungan opini masyarakat yang diwakili oleh pengguna Twitter terhadap suatu topik tertentu.

\section{B. Analisis Sentimen}

Analisis sentimen atau disebut juga Opinion Mining adalah bidang studi yang menganalisis opini, sentimen, evaluasi, penilaian, sikap, dan emosi orang terhadap entitas seperti produk, layanan, organisasi, individu, masalah, acara, topik, dan atributnya [2]. Analisis sentimen pada media sosial saat ini menjadi dapat dilakukan karena semakin banyaknya masyarakat yang menggunakan media sosial sebagai media untuk menyuarakan pendapat pribadi mereka.

\section{Nä̈ve Bayes}

Nä̈ve Bayes adalah teknik klasifikasi berbasis teorema bayes yang merupakan prinsip peluang statistika dengan mengkombinasikan pengetahuan sebelumnya dengan pengetahuan baru [3]. Algoritma klasifikasi Nä̈ve Bayes dipilih dalam penelitian kali ini karena metode klasifikasi Nä̈ve Bayes adalah algoritma klasifikasi yang berguna dalam penggunaan dataset yang besar, selain itu algoritma klasifikasi Naïve Bayes juga merupakan salah satu metode klasifikasi yang sederhana namun memiliki kemampuan dan akurasi tinggi [4]. Kekurangan dari algoritma klasifikasi Nä̈ve Bayes adalah ketika data tidak seimbang maka algoritma klasifikasi Nä̈ve Bayes akan memberikan pembobotan menjadi bias kepada kelas yang lebih banyak [5]. Pada penelitian ini algoritma klasifikasi Naïve Bayes yang akan dipakai adalah Multinomial Nä̈ve Bayes dan Complement Nä̈ve Bayes.

1) Multinomial Nä̈ve Bayes: Multinomial Nä̈ve Bayes adalah model pengembangan dari algoritma klasifikasi Nä̈ve Bayes dimana kelas tidak hanya ditentukan dengan kata yang muncul, tapi juga dengan jumlah kemunculannya sehingga cocok untuk klasifikasi teks atau dokumen, terlebih lagi untuk ukuran dokumen yang besar [6].

2) Complement Nä̈ve Bayes: Complement Nä̈ve Bayes adalah model pengembangan dari algoritma klasifikasi Nä̈ve Bayes yang cenderung memiliki performa yang lebih baik dalam klasifikasi ketika kelas dalam dataset tidak seimbang [7]. Perbedaan dengan Multinomial Nä̈ve Bayes adalah Complement Nä̈ve Bayes Menggunakan data train yang seimbang dari tiap kelas sehingga dapat mengurangi bias yang ada karena dataset tidak seimbang [5].

\section{Neural Network}

Neural Network adalah sistem model komputansi yang terinspirasi oleh jaringan neuron biologis, dimana neuron menghitung nilai output berdasarkan input [8]. Neural Network mengumpulkan pengetahuannya dengan mendeteksi pola dan hubungan dalam data [9]. Neural Network dianggap lebih baik karena Neural Network memiliki kemampuan untuk menemukan pola tersembunyi dalam data [10]. Pada penelitian ini model dari Neural Network yang digunakan adalah Recurrent Neural Network, Long Short-Term Memory, Gated Recurrent Unit, Convolutional Neural Network, dan kombinasi dari Convolutional Neural Network dan Long Short-Term Memory.

1) Recurrent Neural Network: Recurrent Neural Network adalah kelas Neural Network dimana koneksi antara unit membentuk siklus terarah sehingga menghasilkan keadaan internal dari network yang memungkinkannya untuk menunjukan perilaku dinamis yang sementara [11]. Recurrent Neural Network secara natural cocok untuk memproses time series data dan sequential data [12]. Pada klasifikasi teks, model berbasis Recurrent Neural Network melihat teks sebagai urutan kata, dengan maksud untuk menangkap dependensi kata dan struktur teks [10]. Recurrent Neural Network memiliki masalah Vanishing Gradient atau kondisi dimana Long Term Component bergerak secara eksponensial dengan cepat ke norma 0 , sehingga mustahil untuk model untuk mempelajari korelasi antara kondisi yang bersifat sementara [13]. 
2) Long Short-Term Memory: Long Short-Term Memory adalah perkembangan dari model Recurrent Neural Network yang diperkenalkan untuk mengurangi masalah Vanishing Gradient [14]. Long Short-Term Memory dapat mengurangi masalah Vanishing Gradient dengan memperkenalkan Memory Cell untuk mengingat Value selama interval waktu, dan juga memperkenalkan tiga Gate yaitu Input Gate, Output Gate, dan Forget Gate untuk mengatur aliran informasi masuk dan keluar dari Cell sehingga dapat menangkap Long-Term Dependencies dengan lebih baik [10]. Long Short-Term Memory merupakan perkembangan model Recurrent Neural Network yang paling popular saat ini [12].

3) Gated Recurrent Unit: Gated Recurrent Unit diperkenalkan [15] untuk membuat setiap Recurrent Unit secara adaptif menangkap dependensi dari skala waktu yang berbeda [16]. Gated Recurrent Unit merupakan alternative yang lebih sederhana dibandingkan Long Short-Term Memory dan juga cukup popular [12]. Sama seperti Long Short-Term Memory, Gated Recurrent Unit juga dapat mengurangi masalah Vanishing Gradient dari Recurrent Neural Network [20].

4) Convolutional Neural Network: Convolutional Neural Network adalah Feed Forward Neural Network yang khusus digunakan untuk memproses data yang dapat disajikan secara terpisah [17]. Sebagian besar Convolutional Neural Network melibatkan tiga tahap yaitu: Convolution Operation, Activation Function seperti Rectified Linear Activation Function (ReLU) [18], dan Pooling Function seperti Maxpooling [19]. Convolution Operation rata-rata memiliki bobot atau memiliki Smooth Estimation dari Windowed Input. Salah satu kelebihan dari Convolution Operation adalah koneksi antara node dalam jaringan menjadi lebih jarang dengan mempelajari fitur yang kurang penting. Selain itu manfaat dari Convolution Operation adalah parameter sharing. Convolutional Neural Network membuat asumsi bahwa kernel yang dipelajari untuk satu posisi input dapat digunakan disetiap posisi. Convolution Operator sering kali meningkatkan kemampuan learning dari jaringan [20]. Pooling Function berfungsi menggantikan output dari spesifik node terdekat dengan kesimpulan statistik. Motivasi dibalik penambahan Pooling Layer adalah secara statistik melakukan Down-Sampling sejumlah fitur sehingga membuat representasi invariant dengan terjemahan kecil dari input dengan mempertahankan fitur penting [20]. Output akhir akan dihasilkan melalui FullyConnected Layer yang terletak setelah Convolutional Layer dan Maxpooling [20].

5) CNN-LSTM: CNN-LSTM adalah gabungan dari arsitektur Convolutional Neural Network dan Long ShortTerm Memory untuk mendapatkan keuntungan dari kelebihan masing-masing arsitektur dengan cara menggunakan Convolutional Neural Network untuk mengekstrak urutan representasi dari frasa tingkat tinggi, dan dimasukkan ke dalam Long Short-Term Memory untuk mendapatkan representasi kalimat [21].

\section{E. Metrik Penilaian}

Pada penelitian kali ini metrik penilaian yang akan digunakan adalah Skor F1. Nilai akurasi tidak dipakai pada klasifikasi dengan dataset dengan kelas yang tidak seimbang karena nilai akurasi merupakan rasio prediksi kelas yang benar dari keseluruhan data sehingga hasil dari perhitungannya akan memberikan nilai sesuai dengan kelas mayoritas semata [22].

Nilai Skor $F 1$ akan dijadikan acuan penilaian karena nilai F1 melakukan perhitungan dengan menggunakan bobot dari nilai presisi dan recall. Dimana nilai presisi adalah rasio perhitungan kelas yang tepat dari semua kelas yang diprediksi sehingga cocok untuk dijadikan nilai akurasi dari kelas minoritas, sedangkan recall adalah rasio prediksi kelas yang benar dibandingkan keseluruhan data yang benar. Kombinasi perhitungan yang harmonis terhadap hasil presisi dan recall dengan rumus yang dapat dilihat pada formula nomor 1:

$$
\text { Skor } F 1=\frac{2 *(\text { Recall } * \text { Presisi })}{(\text { Recall }+ \text { Presisi })}
$$

Rumus tersebut akan menghasilkan skor Fl dan sangat representatif sebagai metrik evaluasi untuk dataset dengan kelas yang tidak seimbang [22].

\section{Sumber DATA DAN METODOlOGI}

Sumber Data yang digunakan berasal dari media sosial Twitter, dan menggunakan library python GetOldTweets3 untuk melakukan pengambilan data. Data yang diambil dengan menggunakan library GetOldTweets 3 adalah data dengan kriteria pengambilan data Text Query atau teks Tweets, Language, Max Tweets, Since, dan Until. Dengan parameter keywords sebagai kata kunci untuk topik pengambilan data, Start Date sebagai tanggal awal pengambilan data, End Date sebagai batasan tanggal akhir pengambilan data, dan Count yang berfungsi untuk menentukan jumlah data yang akan diambil dari Twitter, dimana jika nilai untuk Count diberikan menjadi 0 maka akan mengambil seluruh data yang memungkinkan dari kata kunci dengan ketentuan jeda waktu Tweets antara nilai Start Date dan End Date [23]. Hasil pengambilan data akan disimpan menjadi format CSV. Gambar 1 adalah diagram alur pengambilan data di Twitter dengan library GetOldTweets3.

\section{A. Twitter}

Kata kunci kunci yang menjadi topik penelitian adalah 'Maranatha', 'marnath', dan 'marnat' dengan konteks yang diinginkan berhubungan dengan Universitas Kristen Maranatha. Berdasarkan data yang diambil dengan jangka waktu 1 januari 2018 hingga 31 desember 2019 didapatkan data sebanyak 17.304 Tweets. Tweets yang telah didapat tersebut akan dipilih secara manual agar semua Tweets yang ada adalah Tweets yang sesuai dengan konteks kata kunci 
yang diinginkan. Jumlah Tweets setelah dipilih adalah 5.367 Tweets. Setelah Tweets dipilih maka kata-kata yang tidak baku dan kata-kata dari bahasa daerah dinormalisasi, sehingga kata-kata dengan konteks yang sama akan menjadi satu kata.

Setelah itu Tweets yang didapat akan diberi label secara manual 1 yang berarti positif, 0 yang berarti netral, dan -1 yang berarti negatif. Setelah pemberian label maka didapat data positif sebanyak 970 data, data netral sebanyak 3.907 data, dan data negatif sebanyak 491 data. Berdasarkan data tersebut dapat disimpulkan data yang digunakan pada penelitian ini merupakan data yang tidak seimbang sehingga dibutuhkan metode resampling untuk mengatasinya.

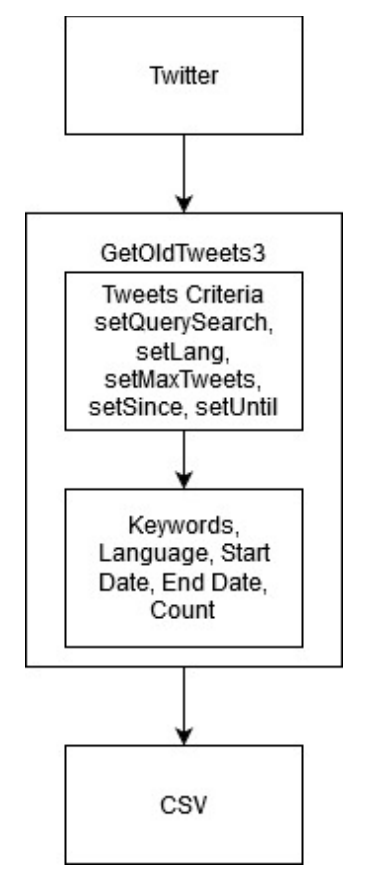

Gambar 1. Diagram alur pengambilan data

\section{B. GetOldTweets3}

GetOldTweets3 adalah library khusus python3 yang digunakan untuk mengakses Tweets lama [23]. Library GetOldTweets3 dipilih sebagai alat untuk pengambilan Tweets lama di Twitter karena Twitter Official API memiliki batasan waktu dalam pengunaannya. Twitter Official API tidak menyediakan akses ke Tweets lama yang lebih lama dari seminggu. Selain itu Twitter Official API memilik batas pengambilan 180 data per 15 menit [24]. Cara kerja library GetOldTweets3 adalah dengan meniru fungsi search Twitter pada browser dengan cara memasukkan kata kunci dan melakukan scroll ke bawah untuk mendapatkan data yang di-post lebih terdahulu [23].

Pengaturan yang dilakukan pada library GetOldTweets3 adalah dengan kata kunci 'Maranatha', 'marnath', dan 'marnat'. Selanjutnya adalah dengan mengatur pembatasan pengambilan data yaitu dengan Start Date tanggal 2018-01-
01 dan End Date tanggal 2019-12-31 dengan Count diberi nilai 0 untuk pengambilan semua data yang ada dari jeda waktu tersebut. Data yang diambil adalah data yang berbahasa Indonesia saja, teks Tweets dan tanggal posting Tweets dan hasilnya akan disimpan dalam format CSV.

\section{Data Cleaning}

Proses Data Cleaning adalah proses untuk mengubah data yang tidak terstruktur menjadi data yang terstruktur [25]. Hasil contoh dari proses data tweets awal, data yang dinormalisasi, dan data yang sudah mengalami proses data cleaning akan dapat dilihat di Tabel I. Proses data cleaning yang dilakukan adalah:

1) Case Folding: Case Folding adalah proses mengubah semua data teks menjadi huruf kecil.

2) Cleansing: Cleansing adalah menghapus data yang dianggap noise. Dalam penelitian ini data yang dihapus adalah tanda baca, angka, teks dengan pattern tertawa yaitu haha, hehe, hihi, wkwk, dan kwkw, spasi berlebih, mention username, dan hapus link yang ada pada data Tweets. Selain itu dilakukan juga penghapusan stopwords dengan menggunakan library PySastrawi. Stopwords adalah adalah kata-kata tidak berarti yang memiliki kekuatan diskriminasi rendah [26]. Stopwords sering dihilangkan pada tahapan preprocessing karena dianggap memiliki nilai informasi yang rendah [27].

3) Stemming: Stemming adalah mereduksi kata menjadi bentuk akarnya atau akar semantiknya [28]. Stemming adalah alat preprocessing teks yang sering digunakan untuk text retrieval yang efisien [29], machine translation [30], document summarization [31] dan text classification [32].

TABEL I

CONTOH PRoses Data CLEANING PADA TWEETS

\begin{tabular}{|l|l|l|l|}
\hline \multicolumn{1}{|c|}{ Tweets Awal } & \multicolumn{1}{|c|}{$\begin{array}{c}\text { Setelah } \\
\text { Normalisasi }\end{array}$} & $\begin{array}{c}\text { Setelah } \\
\text { Normalisasi } \\
\text { dan Cleaning }\end{array}$ & $\begin{array}{c}\text { Nilai } \\
\text { Sentimen }\end{array}$ \\
\hline $\begin{array}{l}\text { Saya mainnya ke } \\
\text { daerah marnath } \\
\text { doang pak }\end{array}$ & $\begin{array}{l}\text { Saya mainnya } \\
\text { ke daerah } \\
\text { marnath saja } \\
\text { pak }\end{array}$ & $\begin{array}{l}\text { main daerah } \\
\text { marnath pak }\end{array}$ & 0 \\
\hline $\begin{array}{l}\text { KampusQ } \\
\text { maranatha yg kaya } \\
\text { mall }\end{array}$ & $\begin{array}{l}\text { Kampus saya } \\
\text { maranatha yang } \\
\text { seperti mall }\end{array}$ & $\begin{array}{l}\text { kampus } \\
\text { maranatha } \\
\text { seperti mall }\end{array}$ & 1 \\
\hline $\begin{array}{l}\text { Sekolah di Bintaro, } \\
\text { global jaya. Urg ge } \\
\text { di marnath basa eta } \\
\text { ngan 80rb / sks }\end{array}$ & $\begin{array}{l}\text { Sekolah di } \\
\text { Bintaro, global } \\
\text { jaya. saya juga } \\
\text { di marnath } \\
\text { waktu itu hanya } \\
\text { 80 ribu / sks }\end{array}$ & $\begin{array}{l}\text { sekolah } \\
\text { bintaro global } \\
\text { jaya juga } \\
\text { marnath } \\
\text { waktu hanya } \\
\text { ribu sks }\end{array}$ & 0 \\
\hline $\begin{array}{l}\text { Sarua euy hanjakal } \\
\text { oge ningali umak } \\
\text { nyanyi teknik } \\
\text { industri ada di } \\
\text { maranatha pas } \\
\text { ospek }\end{array}$ & $\begin{array}{l}\text { Sama menyesal } \\
\text { juga melihat } \\
\text { umak nyanyi } \\
\text { teknik industri } \\
\text { ada di } \\
\text { maranatha pas } \\
\text { ospek }\end{array}$ & $\begin{array}{l}\text { sama sesal } \\
\text { lihat umak } \\
\text { nyanyi teknik } \\
\text { industri di } \\
\text { maranatha pas } \\
\text { ospek }\end{array}$ & -1 \\
\hline $\begin{array}{l}\text { DI DEKET } \\
\text { MARNAT }\end{array}$ & $\begin{array}{l}\text { MARNAT } \\
\text { bagus sekali }\end{array}$ & 1 \\
\hline
\end{tabular}




\begin{tabular}{|c|c|c|c|}
\hline Tweets Awal & $\begin{array}{c}\text { Setelah } \\
\text { Normalisasi }\end{array}$ & $\begin{array}{c}\text { Setelah } \\
\text { Normalisasi } \\
\text { dan Cleaning }\end{array}$ & $\begin{array}{c}\text { Nilai } \\
\text { Sentimen }\end{array}$ \\
\hline $\begin{array}{l}\text { HAHXHSHSHSHS } \\
\text { BAGUS BGT } \\
\text { TERUS MURAH }\end{array}$ & $\begin{array}{l}\text { BAGUS } \\
\text { SEKALI DAN } \\
\text { MURAH }\end{array}$ & murah & \\
\hline $\begin{array}{l}\text { That's why dari } \\
\text { dulu saya pengin } \\
\text { bgt FK Marnat atau } \\
\text { Atma Jaya. Mereka } \\
\text { lebih jauh } \\
\text { menerapkan } \\
\text { toleransi. Apa daya } \\
\text { engga boleh. Bisa } \\
\text { ngerasain bgt } \\
\text { bedanya sama di } \\
\text { kampusku yg } \\
\text { sekarang }\end{array}$ & $\begin{array}{l}\text { Karena itu dari } \\
\text { dulu saya ingin } \\
\text { sekali fakultas } \\
\text { kedokteran } \\
\text { marnat atau } \\
\text { AtmaJaya. } \\
\text { Mereka lebih } \\
\text { jauh terapkan } \\
\text { toleransi. Apa } \\
\text { daya tidak } \\
\text { boleh. Bisa } \\
\text { rasakan sekali } \\
\text { beda dengan di } \\
\text { kampus aku } \\
\text { yang sekarang. }\end{array}$ & $\begin{array}{l}\text { itu dulu ingin } \\
\text { sekali fakultas } \\
\text { dokter marnat } \\
\text { atmajaya } \\
\text { lebih jauh } \\
\text { terap toleransi } \\
\text { apa daya } \\
\text { boleh rasa } \\
\text { sekali beda di } \\
\text { kampus aku } \\
\text { sekarang }\end{array}$ & 1 \\
\hline
\end{tabular}

\section{PySastrawi}

PySastrawi atau python sastrawi adalah library python yang berfungsi untuk mengubah kata berbahasa Indonesia menjadi bentuk dasarnya atau stemming [33]. PySastrawi adalah port python dari proyek asli sastrawi yang ditulis dalam PHP [33]. Sastrawi menerapkan algoritma Nazief dan Adriani dalam proses stemming-nya. Proses stemming dari sastrawi sangat bergantung pada kamus kata dasar [34].

\section{E. Feature Extraction}

Feature Extraction atau ektraksi fitur pada klasifikasi teks adalah proses mengeluarkan daftar kata-kata dari data teks dan kemudian mengubahnya menjadi fitur yang dapat digunakan oleh algoritma klasifikasi [35]. Pada penelitian ini ekstraksi fitur yang akan digunakan adalah Bag-ofWords dan TF-IDF untuk algoritma klasifikasi Multinomial Nä̈ve Bayes dan Complement Nä̈ve Bayes, dan juga PreTrained Word Embedding Vector dari FastText untuk Neural Network.

1) Bag-of-Words: Bag-of-Words adalah metode ekstraksi fitur yang membentuk fitur kehadiran dari kata pada dokumen yang digunakan sehingga dapat menentukan frekuensi kata yang ada dalam dokumen [35]. Hasil dari penyimpanan frekuensi akan berbentuk vektor. Kekurangan dari metode ini adalah kata-kata dengan frekuensi yang lebih tinggi akan menjadi dominan dalam data dimana ada kemungkinan kata-kata ini tidak memberikan banyak informasi untuk model sehingga kata-kata spesifik yang kemungkinan memberikan lebih banyak informasi menjadi diabaikan [35].

2) TF-IDF: TF-IDF atau Term Frequency Inverse Document Frequency adalah metode ekstraksi fitur yang mengatasi kekurangan dari metode Bag-of-Words dimana frekuensi kata-kata dihitung ulang dengan mempertimbangkan seberapa sering kata-kata tersebut muncul di semua dokumen [35]. TF atau Term Frequency adalah frekuensi kata-kata yang ada pada dokumen, dan $I D F$ atau Inverse Document Frequency adalah skor kata-kata dari semua dokumen. Skor ini dapat menyorot kata-kata yang unik dan kata-kata yang mewakili informasi yang diperlukan dalam dokumen tertentu [35].

3) Word Embedding Vektor FastText: FastText adalah library yang dikembangkan oleh FaceBook untuk klasifikasi dan representasi teks dimana FastText mengubah teks menjadi vektor berkelanjutan yang dapat digunakan pada tugas terakit bahasa apapun [36]. FastText berkerja dengan cara mengekstrak semua kata dengan $n$-gram untuk mempelajari representasi dari setiap kata [37]. Penelitian ini akan menggunakan Pre-Trained Word Vectors MultiLingual dengan Bahasa Indonesia dari FastText [36].

\section{F. Cross Validation StratifiedKFold}

Cross Validation StratifiedKFold adalah Cross Validation dengan metode stratification. Stratification adalah pendekatan untuk mempertahankan proporsi kelas yang asli dalam subsets yang dihasilkan [38]. Stratified $K$ Fold adalah pendekatan validasi yang cocok untuk dataset tidak seimbang [39] sehingga cocok digunakan untuk penelitian ini karena data yang digunakan pada penelitian ini merupakan data dengan distribusi kelas yang tidak seimbang.

\section{G. Imbalanced Data}

Imbalanced Data atau data dengan kelas tidak seimbang yang akan digunakan pada penelitian ini adalah data yang berjumlah 5367 data dan dibagi menjadi 970 data kelas positif, 3907 data kelas netral, dan 491 data kelas negatif. Tabel II adalah contoh data Tweets dengan kelas sentimennya.

TABEL III

CONTOH Kelas SENTIMEN PaDa Data TWEetS

\begin{tabular}{|l|c|}
\hline \multicolumn{1}{|c|}{ Tweet } & Sentiment \\
\hline Maranatha mahal ya. . & Negatif \\
\hline jurusan IT maranatha kak? aku SI kwkwkw & Netral \\
\hline Maranatha terbaik emang & Positif \\
\hline marnat itu mahal & Negatif \\
\hline marnat sudah libur kok & Netral \\
\hline $\begin{array}{l}\text { ingin pindah ke marnat ternyata besar sekali dan } \\
\text { bagus sekali }\end{array}$ & Positif \\
\hline Marnath seram kalau malam begini & Negatif \\
\hline marnath kalau tidak salah masih buka & Netral \\
\hline marnath kak, insyaallah yang terbaik deh :') & Positif \\
\hline
\end{tabular}

Berdasarkan jumlah data tersebut maka dapat disimpulkan data yang dimiliki adalah data dengan kelas yang tidak seimbang. Untuk mengatasi ketidakseimbangan dalam kelas data dibutuhkan metode resampling untuk menyeimbangkan data. Metode resampling dapat berupa Over Sampling, Under Sampling, dan kombinasi keduanya. Pada penelitian kali ini metode resampling data yang akan digunakan untuk mengatasi data dengan kelas yang tidak seimbang adalah metode gabungan dari over sampling dan 
under sampling yaitu SMOTETomek. Dan hasil resampling akan dilihat efeknya pada algoritma klasifikasi dan arsitektur Neural Network yang dipilih.

1) SMOTE: SMOTE atau Synthetic Minority Oversampling Technique adalah metode Over Sampling dengan menambahkan data kelas minoritas dengan membuat data sintetis terhadap kelas minoritas [40].

2) Tomek Links: Tomek Links adalah metode Under Sampling dengan menggunakan Nearest-Neighbour Rule dimana mendeteksi 2 kelas berbeda yang berdekatan. Dan menghapus data dari kelas mayoritas [41].

3) SMOTETomek: SMOTETomek adalah metode gabungan antara Over Sampling dan Under Sampling. Dimana data kelas minoritas ditambahkan dengan metode SMOTE, dan data kelas mayoritas yang berdekatan dengan kelas minoritas akan dikurangi dengan TomekLinks sehingga distribusi kelas yang diinginkan tercapai [39]. Strategi yang digunakan untuk resampling data menggunakan SMOTETomek pada penelitian kali ini adalah melakukan SMOTE dengan sampling strategy not majority, dan TomekLinks dengan sampling strategy majority. Hasil dari resampling pada data train dengan menggunakan SMOTETomek akan dapat dilihat pada Gambar 2.

Hasil SMOTETomek pada train data label positif: 2929
Hasil SMOTETomek pada train data label neutral: 2929
Hasil SMOTETomek pada train data label negatif: 2929

Gambar 2. Hasil resampling pada data train

\section{RANCANGAN SISTEM}

Bagian ini akan menjelaskan rancangan sistem dari analisis sentimen dengan menggunakan metode algoritma klasifikasi Nä̈ve Bayes dan Neural Network.

\section{A. Nä̈ve Bayes}

Data yang terdapat pada media sosial Twitter akan diambil berdasarkan kata kunci sebagai topik dengan menggunakan library GetOldTweets3 dengan Tweets kriteria adalah Tweets berbahasa Indonesia saja yang terdapat pada rentang waktu 1 Januari 2018 dan 31 Desember 2019. Data yang diambil akan disimpan dalam bentuk dokumen $C S V$. Data tersebut akan dinormalisasi secara manual. Tahapan normalisasi data yang dilakukan adalah dengan memilih Tweets yang didapat agar dataset hanya berisi kata kunci dengan topik yang diinginkan saja, mengubah kata-kata dengan sinonim berbeda tetapi memiliki konteks yang sama menjadi satu kata, menerjemahkan bahasa daerah menjadi Bahasa Indonesia tanpa merubah konteksnya, mengubah singkatan-singkatan agar menjadi bentuk aslinya, menghapus username, dan hashtag pada data Tweets, dan menyatukan nama tempat atau jalan yang terdiri lebih dari satu kata menjadi satu kata saja. Setelah tahapan normalisasi data Tweets akan di beri label sentimen secara manual dimana 1 berarti positif, 0 berarti netral, dan -1 berarti negatif. Setelah itu data akan dipreprocessing atau dibersihkan dengan cara mengubah data menjadi undercase, menghapus tanda baca, angka, spasi berlebih, link, dan teks dengan konteks tertawa dengan pola haha, hehe, hihi, dan wkwk. Kemudian preprocessing selanjutnya adalah menghapus stop words dari data Tweets, dan melakukan stemming atau mengubah kata-kata pada data menjadi bentuk dasarnya. Setelah proses preprocessing selesai, data akan di bagi dengan menggunakan metode Cross Validation StratifiedKFold menjadi 2 yaitu data train dan data test.

Setelah itu data train dan data tes akan diubah menjadi bentuk vektor pada bagian ekstraksi fitur. Ekstraksi fitur yang dipilih adalah metode Bag-of-Words dan TF-IDF. Setelah data di ubah menjadi vektor maka data train akan di resampling dengan menggunakan metode SMOTETomek agar data yang tidak seimbang dapat menjadi data dengan distribusi yang seimbang. Setelah data train memiliki distribusi kelas yang seimbang, data train akan diaplikasikan menggunakan algoritma klasifikasi Multinomial Nä̈ve Bayes dan Complement Nä̈ve Bayes. Selain itu data train awal dengan bentuk vektor hasil ekstraksi fitur tanpa resampling juga akan langsung diaplikasikan ke algoritma klasifikasi sebagai pembanding dengan hasil resampling. Hasil penilian algoritma klasifikasi adalah nilai dari skor $F 1$. Gambar 3 memberikan rancangan sistem dari algoritma klasifikasi Nä̈ve Bayes. 


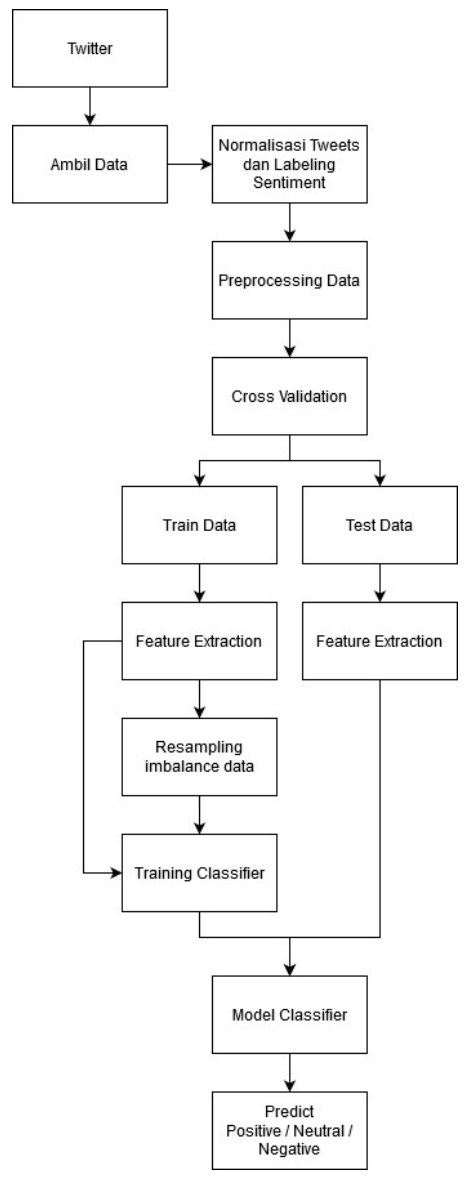

Gambar 3. Rancangan sistem algoritma klasifikasi Nä̈ve Bayes

\section{B. Neural Network}

Rancangan sistem pada metode Neural Network dari proses pengambilan data hingga preprocessing data sama dengan yang dilakukan pada metode Nä̈ve Bayes, tapi pada Neural Network proses pembagian dataset akan dibagi menjadi 3 dataset, yaitu data train, data validation, dan data test. Data train akan digunakan untuk data training, sementara data validation akan digunakan sebagai data untuk validasi arsitektur Neural Network dan test data adalah data yang akan digunakan sebagai data test pada model Neural Network. Setelah proses pembagian dataset maka data train akan di resampling agar distribusi kelasnya seimbang dengan menggunakan metode SMOTETomek.

Penelitian ini menggunakan Pre-Trained Word Embedding Vector dari FastText yang akan digunakan pada arsitektur Neural Network sebagai ekstraksi fitur. Selain itu data train yang tidak mengalami resampling juga akan diaplikasikan ke arsitektur Neural Network sebagai pembanding. Hasil arsitektur Neural Network akan berupa nilai skor F1. Gambar 4 merupakan Gambaran rancangan sistem dari arsitektur Neural Network.

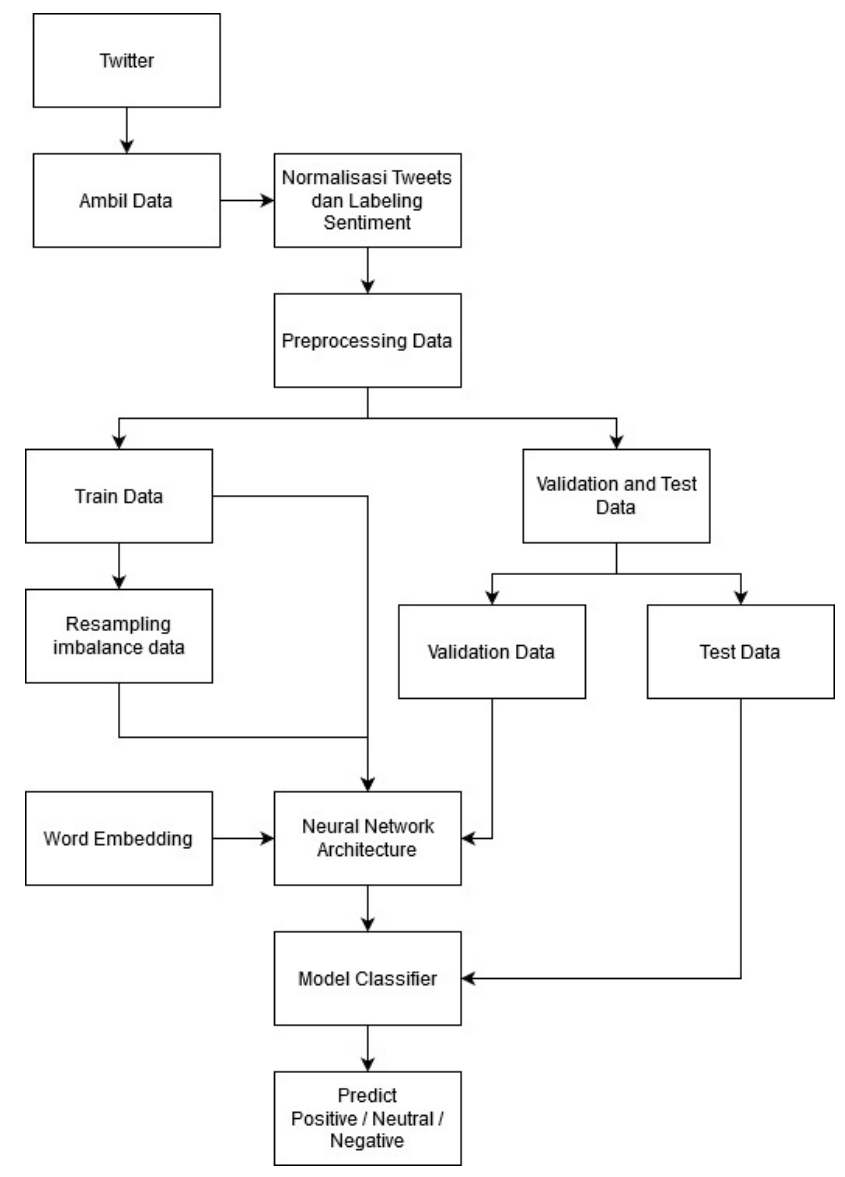

Gambar 4. Rncangan sistem Neural Network

\section{IMPLEMENTASI SISTEM}

Penelitian ini akan membandingkan hasil dari model training menggunakan metode klasifikasi Multinomial Nä̈ve Bayes dan Complement Nä̈ve Bayes. Selain itu metode Neural Network juga akan dicoba sebagai pembanding. Selain itu hasil perbandingan dari input yang sudah di-resampling dengan metode SMOTETomek akan dibandingkan dengan hasil dari input yang tidak diresampling.

Pada algoritma klasifikasi Nä̈ve Bayes akan menggunakan ekstraksi fitur Bag-of-Words dan TF-IDF yang sudah di jadikan bentuk vektor dengan library sckitlearn, dan juga Cross Validation dengan metode StratifiedKFold dengan library sckit-learn. Sedangkan pada Neural Network ekstraksi fitur kan menggunakan PreTrained Word Embedding Vector dari FastText.

Hasil model arsitektur Neural Network juga akan dibandingkan dengan input sebelum resampling dan hasil dengan input setelah resampling dengan SMOTETomek. Proses resampling data akan dilakukan pada data train setelah dataset dibagi antara data train, data validation, dan data test. 


\section{A. Multinomial Nä̈ve Bayes}

Metode yang digunakan pada algoritma klasifikasi Multinomial Nä̈ve Bayes adalah dengan ekstraksi fitur Bagof-Words dan TF-IDF, dan resampling data dengan metode SMOTETomek.

1) Bag-of-Words: Pada ekstraksi fitur Bag-of-Words akan menggunakan CountVectorizer dari library sckit-learn untuk mengubah hasil perhitungan frekuensi antar kata menjadi bentuk vektor, dan dengan nilai n-gram dari 1 sampai 3. Pada parameter untuk resampling data, SMOTE menggunakan resampling strategy not majority untuk menambahkan data pada semua jumlah kelas yang lebih sedikit hingga memiliki jumlah yang sama, dan pada TomekLinks menggunakan sampling strategy majority untuk membersihkan data kelas mayoritas yang berdekatan dengan kelas minoritas. Random state pada setiap pada setiap parameter diberikan nilai 5. Setting parameter yang digunakan pada percobaan dapat dilihat pada Tabel III.

2) TF-IDF: Pada ekstraksi fitur TF-IDF akan menggunakan TFIDFVectorizer dari library sckit-learn. Setting parameter yang digunakan adalah ngram range 1 sampai 3. Pada parameter untuk resampling data, SMOTE menggunakan resampling strategy not majority untuk menambahkan data pada semua jumlah kelas yang lebih sedikit hingga memiliki jumlah yang sama, dan pada TomekLinks menggunakan sampling strategy majority untuk membersihkan data kelas mayoritas yang berdekatan dengan kelas minoritas. Random state pada setiap pada setiap parameter diberikan nilai 5. Setting parameter yang digunakan pada percobaan dapat dilihat pada Tabel III.

TABEL IIIII

SETTING PARAMETER ALGORITMA KLASIFIKASI NAÏVE BAYES

\begin{tabular}{|c|c|c|c|}
\hline Algoritma & Parameter & Deskripsi & Nilai \\
\hline \multirow[t]{2}{*}{$\begin{array}{l}\text { MultinomialNB, } \\
\text { ComplementNB }\end{array}$} & alpha & $\begin{array}{l}\text { smoothing } \\
\text { untuk zero } \\
\text { probability }\end{array}$ & 1 \\
\hline & fit_prior & $\begin{array}{l}\text { pelajari } \\
\text { probabilitas } \\
\text { dari kelas } \\
\text { prior }\end{array}$ & True \\
\hline \multirow[t]{2}{*}{$\begin{array}{l}\text { CountVectorizer, } \\
\text { TFIDFVectorizer }\end{array}$} & max_features & $\begin{array}{l}\text { batas } \\
\text { maksimal } \\
\text { vocabulary }\end{array}$ & None \\
\hline & ngram_range & $\begin{array}{l}\text { range ngram } \\
\text { untuk kata } \\
\text { yang berbeda }\end{array}$ & 1,3 \\
\hline \multirow[t]{2}{*}{ SMOTE } & random_state & $\begin{array}{l}\text { randomization } \\
\text { menggunakan } \\
\text { random } \\
\text { number } \\
\text { generator }\end{array}$ & 5 \\
\hline & sampling_strategy & $\begin{array}{l}\text { menentukan } \\
\text { kelas target } \\
\text { resampling }\end{array}$ & $\begin{array}{l}\text { not } \\
\text { majority }\end{array}$ \\
\hline TomekLinks & random_state & $\begin{array}{l}\text { randomization } \\
\text { menggunakan }\end{array}$ & 5 \\
\hline
\end{tabular}

\begin{tabular}{|l|l|l|l|}
\hline Algoritma & Parameter & Deskripsi & Nilai \\
\hline & & $\begin{array}{l}\text { random } \\
\text { number } \\
\text { generator }\end{array}$ & \\
\hline & sampling_strategy & $\begin{array}{l}\text { menentukan } \\
\text { kelas target } \\
\text { resampling }\end{array}$ & majority \\
\hline SMOTETomek & random_state & $\begin{array}{l}\text { randomization } \\
\text { menggunakan } \\
\text { random } \\
\text { number } \\
\text { generator }\end{array}$ & 5 \\
\hline & & & \\
\hline
\end{tabular}

\section{B. Complement Nä̈ve Bayes}

Metode yang digunakan pada algoritma klasifikasi Complement Nä̈ve Bayes adalah dengan ekstraksi fitur Bagof-Words dan TF-IDF, dan resampling data dengan metode SMOTETomek.

1) Bag-of-Words: Setting parameter yang digunakan pada ekstraksi fitur Bag-of-Words pada algoritma klasifikasi Complement Nä̈ve Bayes sama dengan setting parameter yang dilakukan pada ekstraksi fitur Bag-of-Words pada algoritma klasifikasi Multinomial Nä̈ve Bayes. Setting parameter yang digunakan pada percobaan dapat dilihat pada Tabel III.

2) TF-IDF: Setting parameter yang digunakan pada ekstraksi fitur TF-IDF pada algoritma klasifikasi Complement Nä̈ve Bayes sama dengan setting parameter yang dilakukan pada ekstraksi fitur TF-IDF pada algoritma klasifikasi Multinomial Nä̈ve Bayes. Setting parameter yang digunakan pada percobaan dapat dilihat pada Tabel III.

\section{Neural Network}

Setting parameter yang dilakukan pada semua arsitektur Neural Network adalah pada Input Layer diberikan nilai maksimal panjang data Tweets yang ada pada dataset, nilai input pada Embedding Layer adalah nilai panjang maksimal dari data Tweets yang ada pada dataset dan ukuran dimensi dari Pre-Trained Word Embedding Vector dari FastText, Dropout dengan nilai 0.5 dimana Dropout pada perecobaan kali ini digunakan sebagai Hidden Layer sebelum Output Layer, dan Dense pada Output Layer diberi input sesuai dengan jumlah kelas yang akan diprediksi. Batch Size pada semua arsitektur Neural Network diberikan nilai 12 dan epoch sebanyak 50 kali.

1) RNN: Pada percobaan ini arsitektur Recurrent Neural Network yang akan dipakai adalah SimpleRNN dari library Keras. Dropout yang digunakan adalah SpatialDropout1D dimana berfungsi sebagai Visible Layes sebelum Input Layer dan diberi nilai 0.5. Pada layer SimpleRNN akan diberikan input unit yang berjumlah 16 . Gambar 5 adalah arsitektur RNN yang digunakan. 
2) LSTM: Pada percobaan kali ini arsitektur Long Short-Term Memory yang akan dipakai adalah LSTM dari library Keras. Dropout yang digunakan adalah SpatialDropout1D dimana berfungsi sebagai Visible Layes sebelum Input Layer dan diberi nilai 0.5. Pada arsitektur ini input dari layer LSTM diberikan nilai 128. Gambar 5 adalah arsitektur LSTM yang digunakan.

3) GRU: Pada percobaan kali ini arsitektur Gated Recurrent Unit yang akan dipakai adalah GRU dari library Keras. Dropout yang digunakan adalah SpatialDropout1D dimana berfungsi sebagai Visible Layes sebelum Input Layer dan diberi nilai 0.5. Pada arsitektur ini input dari layer GRU diberikan 16 jumlah unit. Gambar 5 adalah arsitektur $G R U$ yang digunakan.

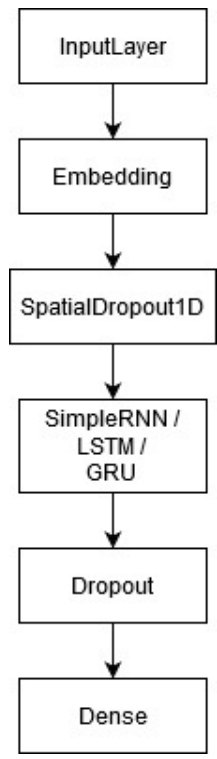

Gmbar 5. Arsitektur RNN, LSTM, dan GRU

4) CNN: Pada percobaan kali ini arsitektur Convolutional Neural Network yang akan dipakai adalah CNN dari library Keras. Pada arsitektur ini Convolutional Layer yang digunakan berjumlah 3-unit dengan Batch Normalization yang berfungsi untuk standarisasi input dan Maxpooling pada setiap unitnya yang kemudian setiap unit akan disatukan pada Concatenate Layer dan akan dijadikan single array pada layer Flatten. Gambar 6 adalah arsitektur CNN yang digunakan.

5) CNN-LSTM: Pada percobaan kali ini arsitektur CNN-LSTM yang akan dipakai adalah CNN dari library Keras dan akan ditambahkan layer LSTM dari library keras. Pada arsitektur ini Convolutional layer yang digunakan memakai setting yang sama dengan setting parameter dari arsitektur CNN yang dilakukan sebelumnya dengan tambahan dan akan disatukan pada concatenate layer kemudian akan dimasukkan sebagai input dari LSTM layer. Hanya saja sebelum Convolutional Layer akan diberi SpatialDropout1D sebagai Visible Layer. Setting parameter dari LSTM layer akan mengikuti setting dari arsitektur
LSTM yang dilakukan sebelumnya yang akan dimasukkan pada layer attention dan dijadikan single array pada layer Flatten. Gambar 7 memperlihatkan arsitektur CNN-LSTM yang digunakan dalam penelitian ini.

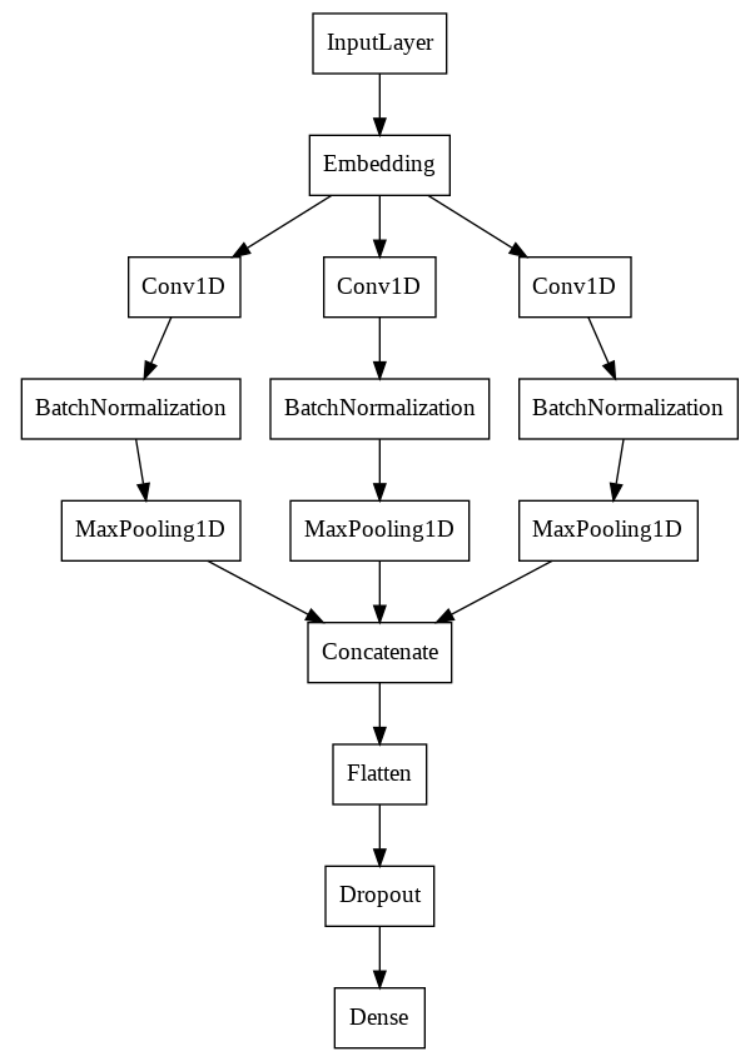

Gambar 6. Arsitektur $C N N$ 


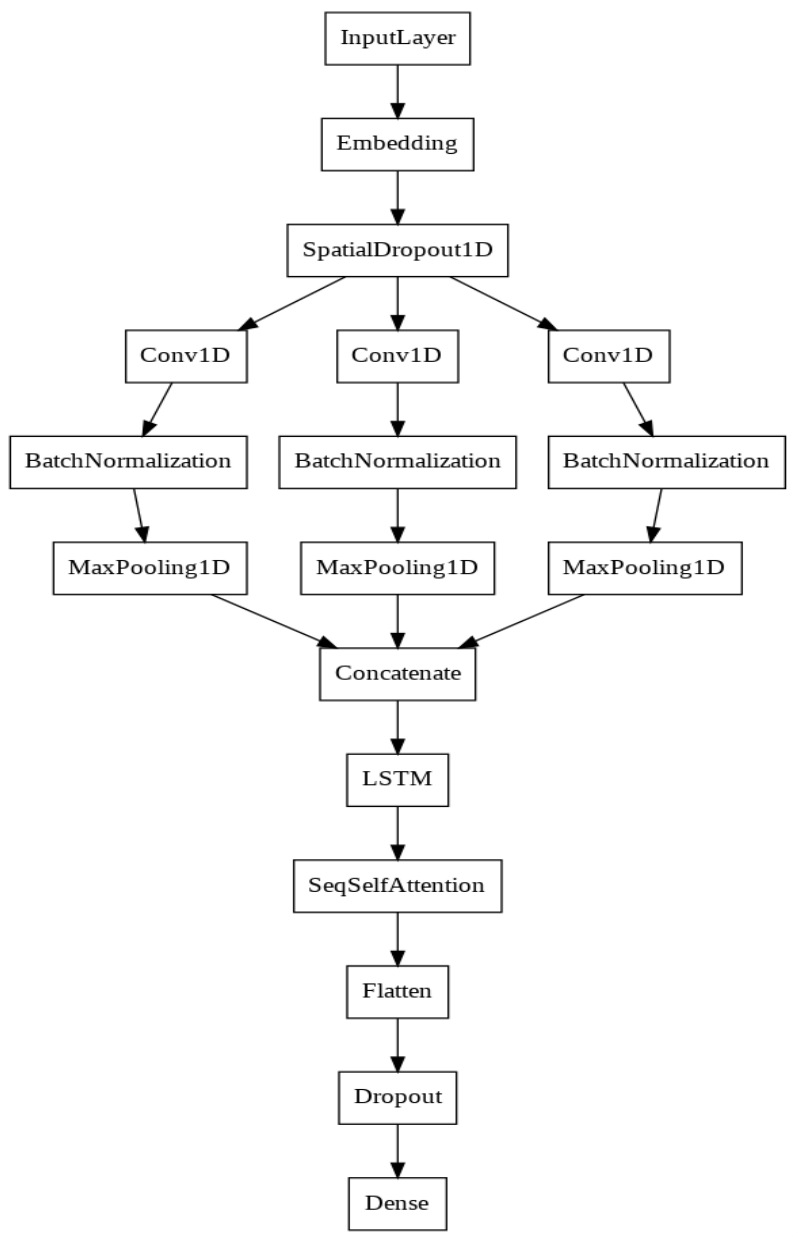

Gambar 7. Arsitektur CNN-LSTM

\section{HASIL EKSPERIMEN DAN EVALUASI}

Bagian ini akan membahas hasil eksperimen yang dilakukan dan evaluasi dari setiap model yang digunakan.

\section{A. Nä̈ve Bayes}

Pada metode dengan algoritma klasifikasi Multinomial Nä̈ve Bayes dengan ekstraksi fitur Bag-of-Words tanpa resampling data menghasilkan model dengan skor $F 1$ sebesar 46.46 dan dengan resampling metode SMOTETomek pada data menghasilkan model dengan skor F1 sebesar 53.64. Sedangkan pada ekstraksi fitur $T F-I D F$ dan algoritma klasifikasi Multinomial Naïve Bayes dengan data tanpa resampling menghasilkan model dengan skor $F 1$ sebesar 31.40 dan dengan data setelah pengaplikasian resampling menghasilkan model dengan skor $F 1$ sebesar 55.48 Gambar 8 adalah hasil perbandingan model dari algoritma klasifikasi Multinomial Nä̈ve Bayes.

Pada metode Complement Nä̈ve Bayes dengan esktraksi fitur Bag-of-Words tanpa resampling data mendapatkan 50.65 dan dengan resampling data menghasilkan model dengan skor $F 1$ sebesar 51.26. Sedangkan pada ekstraksi fitur TF-IDF pada algoritma klasifikasi Complement Nä̈ve Bayes tanpa resampling data menghasilkan model dengan skor F1 sebesar 47.55 dan dengan resampling data menghasilkan model dengan skor $F 1$ sebesar 51.33. Gambar 9 adalah hasil perbandingan model dari algoritma klasifikasi Complement Nä̈ve Bayes.

\section{Multinomial Naive Bayes Summary}

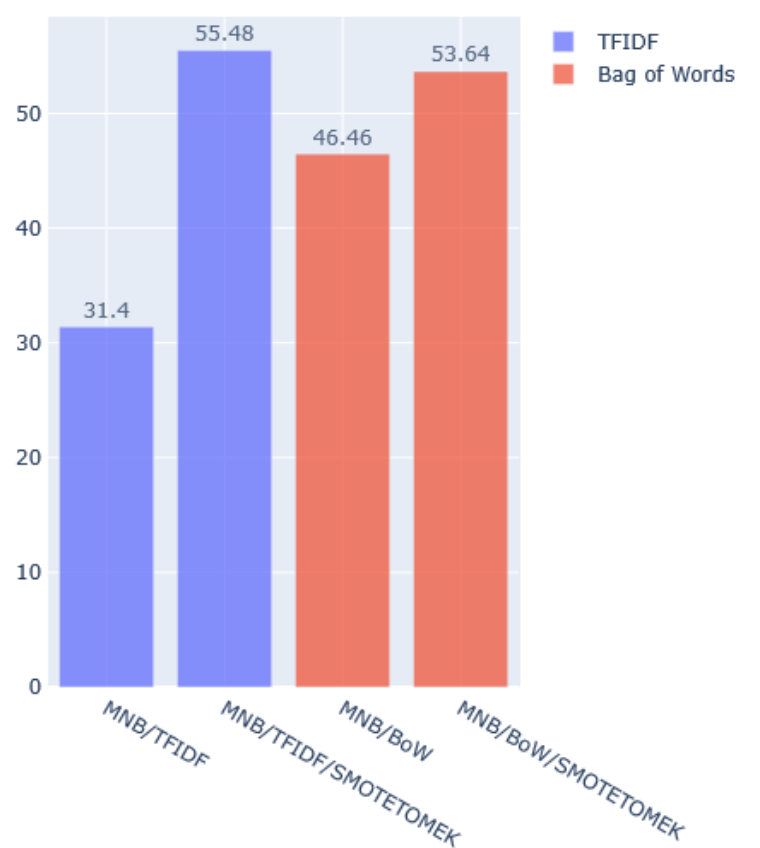

Gambar 8. Perbandingan model Multinomial Nä̈ve Bayes MNB/TFIDF dan $M N B / B o W$ dengan resampling data SMOTETOMEK

Complement Naive Bayes Summary

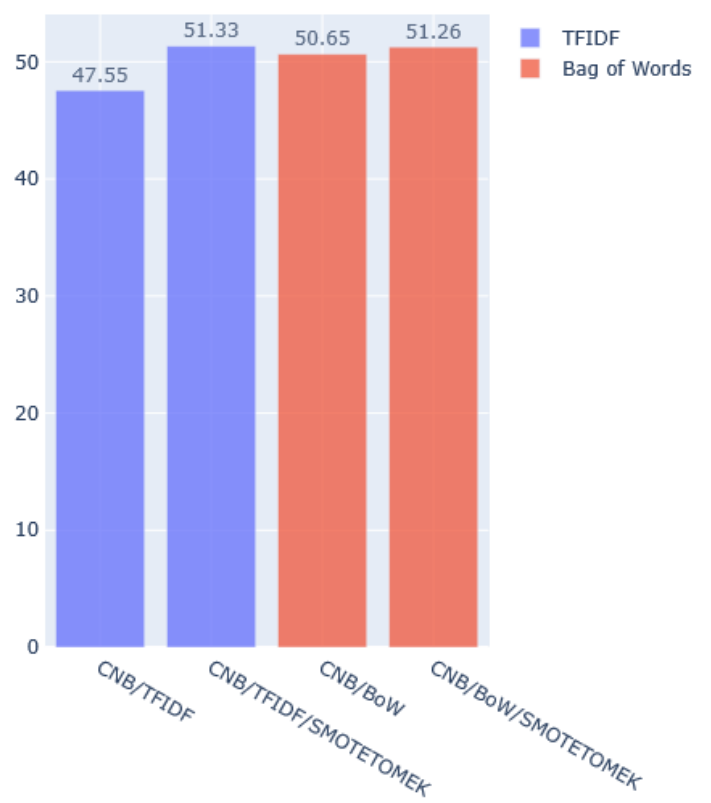


Gambar 9. Perbandingan model Complement Nä̈ve Bayes CNB/TFIDF dan CNB/BoW dengan resampling data SMOTETOMEK

\section{B. Neural Network}

Pada metode Neural Network dengan arsitektur Recurrent Neural Network dengan input tanpa resampling data menghasilkan model dengan skor $F 1$ sebesar 75.70 dan dengan input setelah resampling data menggunakan metode SMOTETomek menghasilkan model dengan skor F1 sebesar 54.89. Gambar 10 adalah hasil perbandingan model dari Recurrent Neural Network.

\section{RNN Summary}

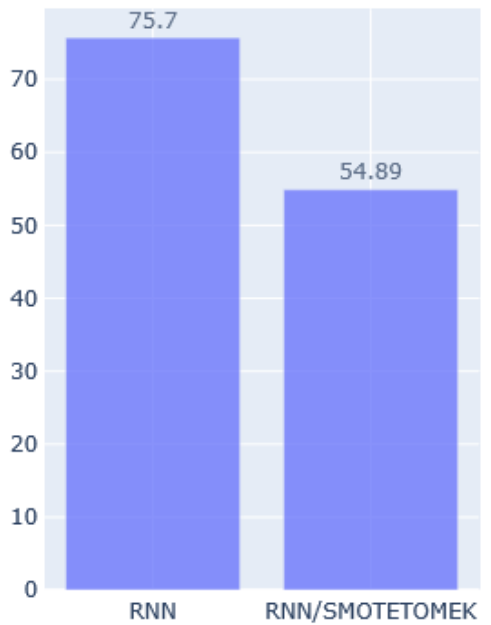

Gambar 10. Perbandingan model $R N N$ dengan resampling data SMOTETOMEK

Pada arsitektur Long Short-Term Memory dengan input tanpa resampling data menghasilkan model dengan skor $F 1$ sebesar 78.36 dan dengan input setelah resampling data menghasilkan model dengan skor F1 sebesar 70.07. Gambar 11 adalah hasil perbandingan model dari Long Short-Term Memory.
LSTM Summary

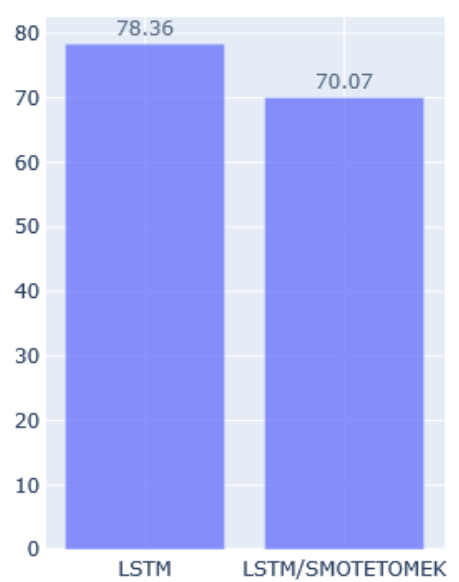

Gambar 11. Perbandingan model LSTM dengan resampling data SMOTETOMEK

Pada arsitektur Gated Recurrent Unit dengan input tanpa resampling data menghasilkan model dengan skor $F 1$ sebesar 77.96, dan dengan input setelah resampling data menghasilkan model dengan skor F1 sebesar 63.06. Gambar 12 adalah hasil perbandingan model dari Gated Recurrent Unit.

\section{GRU Summary}

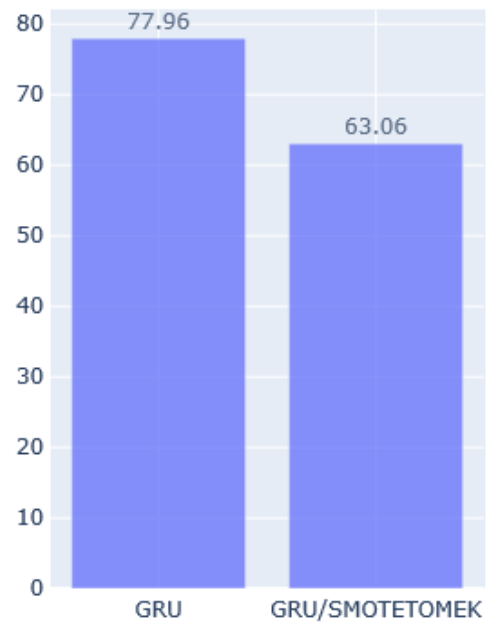

Gambar 12. Perbandingan model GRU dengan resampling data SMOTETOMEK

Pada arsitektur Convolutional Neural Network dengan input tanpa resampling data menghasilkan model dengan skor $F 1$ sebesar 76.12 dan dengan input setelah resampling data menghasilkan model dengan skor $F 1$ sebesar 67.65. Gambar 13 adalah hasil perbandingan model dari Convolutional Neural Network. 


\section{CNN Summary}

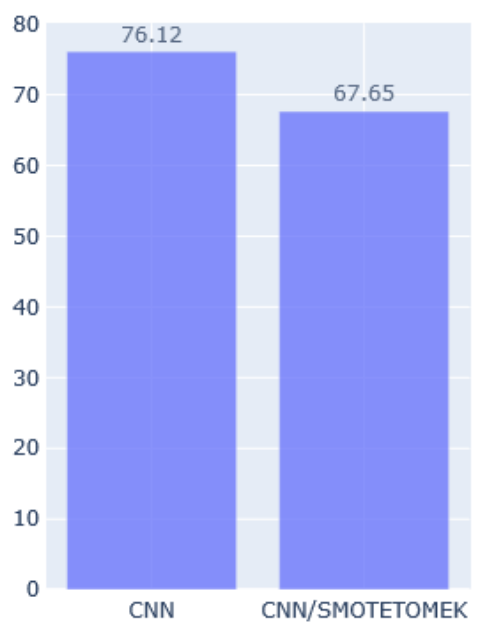

Gambar 13. Perbandingan model $C N N$ dengan resampling data SMOTETOMEK

Pada arsitektur Neural Network gabungan Convolutional Neural Network dan Long Short-Term Memory dengan input tanpa resampling data menghasilkan model dengan skor $F 1$ sebesar 81.14 dan dengan input setelah resampling data menghasilkan model dengan skor $F 1$ sebesar 71.06. Gambar 14 adalah hasil perbandingan model dari $C N N$ LSTM.

\section{CNN-LSTM Summary}

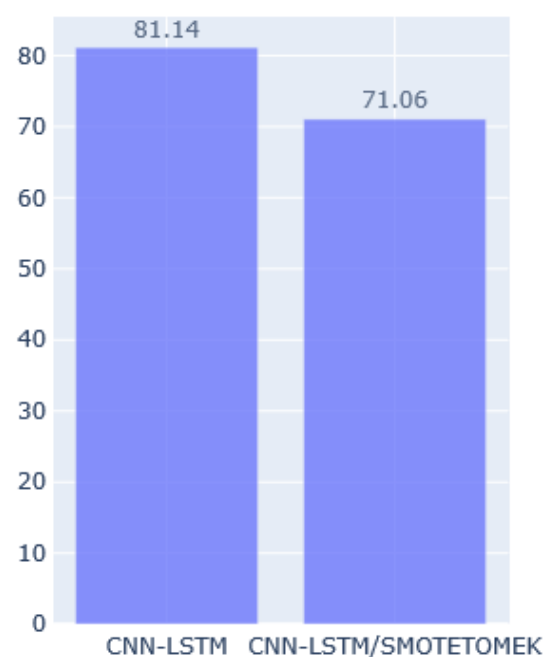

Gambar 14. Perbandingan model CNN-LSTM dengan resampling data SMOTETOMEK

\section{DISKUSI HASIL}

Tabel IV adalah tabel perbandingan hasil dari setiap model dari penelitian ini. Model dengan algoritma klasifikasi Nä̈ve Bayes pada penelitian ini mendapatkan F1 skor terbaik sebesar 55.48 pada model kombinasi dari
Multinomial Nä̈ve Bayes dengan fitur ekstraksi TF-IDF dan resampling data. Sedangkan pada model dengan arsitektur Neural Network pada penelitian ini mendapatkan skor $F 1$ terbaik sebesar 81.14 pada model dengan arsitektur CNN-LSTM.

Selain itu berdasarkan hasil penelitian pada Tabel IV model Multinomial Nä̈ve Bayes dengan ekstraksi fitur TF$I D F$ adalah model dengan skor $F 1$ yang paling rendah. Hal ini disebabkan karena model gagal dalam memprediksi kelas minoritas. Hasil dari performa algoritma klasifikasi Nä̈ve Bayes yang dilakukan menghasilkan model dengan skor Fl yang kurang baik dikarenakan normalisasi dari dataset yang kurang seragam sehingga mempengaruhi hasil dari ekstraksi fitur yang berifat frekuensi dari tiap kata yang ada pada dataset, sementara pada arsitektur Neural Network, hasil cenderung lebih baik karena ekstraksi fitur pada Word Embedding Vector Pre-trained dari FastText mengekstraksi tiap kata dengan $n$-gram untuk mempelajari representasi dari setiap kata [37] yang ada pada dataset sehingga efek dari kurang seragamnya tiap kata dalam dataset dapat diminimalisir.

TABEL IV

HASIL PERBANDINGAN MODEL

\begin{tabular}{|l|c|}
\hline \multicolumn{1}{|c|}{ Metode } & F1 Score \\
\hline MNB/TF-IDF & 31.40 \\
\hline MNB/TF-IDF/SMOTETomek & $\mathbf{5 5 . 4 8}$ \\
\hline MNB/Bag-of-Words & 46.46 \\
\hline MNB/Bag-of-Words/SMOTETomek & 53.64 \\
\hline CNB/TF-IDF & 47.55 \\
\hline CNB/TF-IDF/SMOTETomek & 51.33 \\
\hline CNB/Bag-of-Words & 50.65 \\
\hline CNB/Bag-of-Words/SMOTETomek & 51.26 \\
\hline RNN & 75.70 \\
\hline RNN/SMOTETomek & 54.89 \\
\hline LSTM & 78.36 \\
\hline LSTM/SMOTETomek & 70.07 \\
\hline GRU & 77.96 \\
\hline GRU/SMOTETomek & 63.06 \\
\hline CNN & 76.12 \\
\hline CNN/SMOTETomek & 67.65 \\
\hline CNN-LSTM & $\mathbf{8 1 . 1 4}$ \\
\hline CNN-LSTM/SMOTETomek & 71.06 \\
\hline
\end{tabular}

Untuk menguji lebih lanjut terkait skor $F 1$ pada model dengan hasil terbaik pada algoritma klasifikasi Nä̈ve Bayes dan arsitektur Neural Network akan dilakukan uji signifikansi. Input pengujian berulang akan berupa hasil skor F1 dari 10 kali StratifiedKFold Cross Validation untuk Multinomial Nä̈ve Bayes dan 10 epoch untuk CNN-LSTM, dengan nilai keyakinan yang ditetapkan sebesar $90 \%$. Hasil dari uji signifikansi dari pengujian berulang dapat dilihat pada Tabel V. Dimana pada pengujian menghasilkan skor student t-test sebesar 8.412E-16. Nilai tersebut lebih kecil dibandingkan nilai keyakinan yang ditetapkan yaitu $90 \%$. Dengan demikian terdapat perbedaan yang signifikan antara skor F1 dari skor terbaik algoritma klasifikasi Nä̈ve Bayes dengan skor terbaik dari arsitektur Neural Network. 
TABEL V

SIGNIFIKAN TEST

\begin{tabular}{|c|c|c|}
\hline & $\begin{array}{c}\text { Multinomial } \\
\text { Naïve Bayes }\end{array}$ & CNN-LSTM \\
\hline $\begin{array}{l}\text { Percobaan } \\
\text { ke }\end{array}$ & Skor F1 - MNB & $\begin{array}{c}\text { Skor F1 - CNN- } \\
\text { LSTM }\end{array}$ \\
\hline 1 & 53,97 & 73,16 \\
\hline 2 & 53,87 & 80,28 \\
\hline 3 & 57,19 & 81,19 \\
\hline 4 & 52,93 & 81,82 \\
\hline 5 & 53,52 & 81,30 \\
\hline 6 & 55,58 & 81,18 \\
\hline 7 & 55,27 & 80,92 \\
\hline 8 & 57,77 & 82,10 \\
\hline 9 & 53,62 & 82,00 \\
\hline 10 & 54,52 & 81,13 \\
\hline Rata-rata & 54,82 & 80,51 \\
\hline t-test & \multicolumn{2}{|c|}{$8,41205 \mathrm{E}-16$} \\
\hline Alpha & \multicolumn{2}{|c|}{0,1} \\
\hline
\end{tabular}

Hasil resampling dengan metode SMOTETomek pada algoritma klasifikasi Nä̈ve Bayes memiliki pengaruh dalam menaikan nilai skor F1, terlebih lagi pada algoritma Multinomial Nä̈ve Bayes dimana pertambahan dari persentasi skor F1 lebih banyak dibandingan Complement Nä̈ve Bayes dan juga resampling data menghasilkan performa yang lebih baik jika dikombinasikan dengan fitur ekstraksi $T F-I D F$. Selain itu, dengan kombinasi estraksi fitur TF-IDF dan resampling data SMOTETomek, algoritma klasifikasi Multinomial Nä̈ve Bayes dapat menghasilkan model dengan skor $F 1$ yang lebih tinggi dibandingkan model dengan algoritma klasifikasi Complement Nä̈ve Bayes, dimana algoritma klasifikasi Complement Nä̈ve Bayes adalah algoritma klasifikasi yang cenderung lebih cocok dalam menangani data dengan kelas yang tidak seimbang [7]. Hasil dari resampling data pada Complement Nä̈ve Bayes dengan ekstraksi fitur Bag-of-Words tidak menunjukan hasil dengan peningkatan skor $F 1$ seperti pada Multinomial Naïve Bayes terjadi karena cara kerja dari Complement Nä̈ve Bayes sendiri dimana Complement Nä̈ve Bayes menggunakan data train dari setiap kelasnya dengan seimbang [5] sehingga penyeimbangan dataset sudah dilakukan terlebih dahulu sebelum proses resampling data terjadi.

Sedangkan pada hasil penelitian dengan menggunakan arsitektur Neural Network, hasil dari input dengan resampling data menghasilkan model dengan skor $F 1$ yang lebih kecil dibandingkan tanpa resampling data. Hal ini berbanding terbalik jika dibandingkan dengan hasil dari algoritma klasifikasi Nä̈ve Bayes. Di samping itu, berdasarkan hasil penelitian yang didapat, pengaplikasian metode resampling SMOTETomek pada arsitektur Neural Network paling berpengaruh pada arsitektur CNN dan LSTM dimana kedua arsitektur tersebut memiliki selisih skor Fl dengan input tanpa resampling dan input setelah resampling yang lebih sedikit dibandingkan arsitektur lainnya.

\section{KESIMPULAN}

Pembuatan model analisis sentimen berbahasa Indonesia dengan multi keyword sebagai topik dengan metode algoritma klasifikasi Multinomial Nä̈ve Bayes dan Complement Nä̈ve Bayes sudah berhasil dibuat. Selain itu sebagai pembanding model analisis sentimen dengan arsitektur Neural Network yaitu Recurrent Neural Network, Long Short-Term Memory, Gated Recurrent Unit, Convolutional Neural Network, serta kombinasi dari Convolutional Neural Network dan Long Short-Term Memory pun sudah berhasil dibuat. Hasil yang didapat adalah hampir semua model analisis sentimen dengan arsitektur Neural Network memiliki skor yang lebih baik dibandingkan model dengan algoritma klasifikasi Nä̈ve Bayes. Hasil yang berbeda didapatkan dari model dengan arsitektur Recurrent Neural Network dengan input data setelah resampling menggunakan metode SMOTETomek dimana hasil skornya lebih kecil dari Multinomial Nä̈ve Bayes dengan ekstraksi fitur TF-IDF dan resampling data menggunakan metode SMOTETomek.

Selain itu, hasil resampling data pun sudah dapat diaplikasikan serta diamati perbedaan tiap efeknya dengan algoritma klasifikasi Nä̈ve Bayes maupun arsitektur Neural Network. Dimana efek dari resampling data terhadap skor F1 lebih berpengaruh terhadap algoritma klasifikasi Nä̈ve Bayes dibandingkan arsitektur Neural Network.

\section{SARAN}

Pada penelitian yang lebih lanjut akan dapat menggunakan dataset berbahasa Indonesia dengan data yang lebih banyak dengan label sentimen yang lebih sesuai dengan ilmu linguistic agar dapat meminimalisir bias dari manual labeling. Selain itu data perkelas yang ada pada dataset juga dapat diperbanyak dengan lebih banyaknya jumlah data Tweets pada dataset sehingga dapat menambah jumlah kosakata pada kelas minoritas. Pada setting parameter dapat dicoba untuk mencari parameter yang paling optimal berdasarkan parameter yang ada pada algoritma klasifikasi Naïve Bayes dan fitur ekstraksinya, juga parameter yang ada pada arsitektur Neural Network untuk mencapai akurasi yang lebih optimal. Selain itu dapat dicoba untuk melakukan analisis sentimen yang dapat mendeteksi sarkasme, emoticon, dan negasi. Sedangkan pada Neural Network dapat dicoba untuk melakukan klasifikasi dengan ekstraksi fitur lainnya.

\section{DAfTAR PUSTAKa}

[1] L. J. Sheela, "A Review of Sentiment Analysis in Twitter Data Using Hadoop," International Journal of Database Theory and Application, vol. 9(1), pp. 77-86, May. 2016.

[2] B. Liu, Sentiment Analysis and Subjectivity Handbook of Natural Language Processing, Cambridge, United Kingdom: Cambridge University Press, 2015.

[3] P. N. Tan, M. Steinbach, \& V. Kumar, Introduction to Data Mining. Boston, United States: Pearson Education, 2006. 
[4] I. Rish, "An empirical study of The Naive Bayes Classifier," IJCAI 2001 workshop on empirical methods in artificial intelligence, vol. 3, pp. 41-46, Aug. 2001.

[5] Jason. D. M. Rennie, S. Lawrence, T. Jaime, \& R. K. David, "Tackling the Poor Assumptions of Naive Bayes Text Classifiers," ICML'03 Proceedings of the Twentieth International Conference on Machine Learning, pp. 616-623, Aug. 2003.

[6] I. H. Witten, F. Eibe \& M. A. Hall, Data mining: Practical Machine Learning Tools and Techniques. Third Edition. USA: Elsevier, 2011.

[7] (2020) Sckit-learn website. [Online]. Tersedia: https://scikitlearn.org/stable/modules/generated/sklearn.naive_bayes.Complemen tNB.html/

[8] P. Munish, S. Aum, P. Timothy, Tipparaju M. Srivinas, Moreno W. Alejandro, \& P. Yashwant, "Introduction to Artificial Neural Network (ANN) as a Predictive Tool for Drug Design, Discovery, Delivery, and Disposition: Basic Concepts and Modeling," Artificial Neural Network for Drug Design, Delivery and Disposition, pp. 313, Oct. 2015

[9] R. Priyadarshini, N. Dash, T. Swarnkar, \& R. Misra, "Functional Analysis of Artificial Neural Network for Dataset Classification," ACCTA-2010 Special Issue of IJCCT Vol.1 Issue 2, 3, 4; 2010 for International Conference, Aug. 2010

[10] S. Minaee, N. Kalchbrenner, E. Cambria, N. Nikzad, M. Chenaghlu, \& G. Jianfeng, "Deep Learning Based Text Classification: A Comprehensive Review," 2020; arXiv:2004.03705.

[11] Tatyana I. Poznyak, Isaac Chairez Oria, \& Alexander S. Poznyak, Ozonation and Biodegradation in Environmental Engineering: Dynamic Neural Network Approach. Elsevier, 2018.

[12] R. DiPietro, \& G. D. Hager, Handbook of Medical Image Computing and Computer Assisted Intervention, Chapter 21. pp. 503-519. Academic Press. 2019.

[13] R. Pascanu, T. Mikolov, \& Y. Bengio, "On the difficulty of training recurrent neural networks," ICML'13: Proceedings of the 30th International Conference on International Conference on Machine Learning, pp. III-1310-III-1318, June. 2013.

[14] S. Hochreiter, J. Schmidhuber, "Long short-term memory," Neural Computation, vol 9(8), pp. 1735-1780, Nov. 1997.

[15] K. Cho, B. van Merrienboer, D. Bahdanau, \& Y. Bengio, "On the Properties of Neural Machine Translation: Encoder-Decoder Approaches," 2014; arXiv:1409.1259.

[16] J. Chung, C. Gulcehre, K. Cho, \& Y. Bengio, "Empirical Evaluation of Gated Recurrent Neural Networks on Sequence Modeling," 2014; arXiv:1412.3555.

[17] Y. Lecun, "Generalization and network design strategies," Connectionism in perspective, pp. 143-155, June. 1989.

[18] A. Krizhevsky, I. Sutskever, \& G. E. Hinton, Imagenet classification with deep convolutional neural networks, F. Pereira, C. J. C. Burges, L. Bottou, \& K. Q. Weinberger. Advances in Neural Information Processing Systems 25. pp. 1097-1105, Curran Associates, Inc, 2012.

[19] Y. Zhou, \& R. Chellappa, "Computation of optical flow using a neural network," IEEE 1988 International Conference on Neural Networks," pp. 71-78, July. 1988.

[20] A. Ghods, \& D. J. Cook, "A Survey of Techniques All Classifiers Can Learn from Deep Networks: Models, Optimizations, and Regularization," 2019; arXiv:1909.04791.

[21] C. Zhou, C. Sun, Z. Liu, \& Francis C. M. Lau, "A C-LSTM Neural Network for Text Classification,” 2015; arXiv: 1511.08630.
[22] H. He, \& Y. Ma, Imbalanced Learning: Foundations, Algorithms, and Applications. Wiley-IEEE Press, 2013.

[23] (2020) GetOldTweets3 pip website [Online]. Tersedia; https://pypi.org/project/GetOldTweets3/

[24] (2020) Twitter Developer website [Online]. Tersedia; https://developer.twitter.com/en/docs/basics/rate-limiting/

[25] Asniar, \& B R Aditya. "A Framework for Sentiment Analysis Implementation of Indonesian Language Tweet on Twitter," Journal of Physics: Conference Series, vol. 801(1), article id. 012065. Jan. 2017.

[26] R. T. W. Lo, B. He, \& I. Ounis. "Automatically building a stopword list for an information retrieval system," J. Digit. Inf. Manaag, vol. 5, pp. 17-24. Jan. 2005.

[27] H. Saif, M. Fernandez, Y. He, \& H. Alani. "On Stopwords, Filtering and Data Sparsity for Sentiment Analysis of Twitter," LREC'14 Proceedings of the Ninth International Conference on Language Resources and Evaluation, pp. 810-817. May. 2014

[28] C. T. Meadow, B. R. Boyce, \& D. H. Kraft, Text information retrieval systems, 2nd ed. San Diego, California: Academic Press, 2000.

[29] W. Frakes, Information Retrieval: Data Structures and Algorithms, Englewood Cliffs, New Jersey: Prentice-Hall, 1992.

[30] Z. A. Bakar, \& N. A. Rahman. Evaluating the effectiveness of thesaurus and stemming methods in retrieving Malay translated AlQuran documents, seri Lecture Notes in Computer Science. Digital Libraries: Technology and Management of Indigenous Knowledge for Global Access. pp. 653-662. Springer. 2003.

[31] C. Or asan, V. Pekar, \& L. Hasler. "A comparison of summarisation methods based onterm specificity estimation," LREC'04 Proceedings of the Fourth International Conference on Language Resources and Evaluation. pp. 1037-1041. May. 2004.

[32] T. Gaustad, \& G. Bouma. Computational Linguistics in the Netherlands: Accurate stemming of Dutch for text classification, seri Language and Computers: Studies in Practical Linguistics. Amsterdam: Rodopi, 2002.

[33] (2020) PySastrawi Github website [Online] Tersedia: https://github.com/har07/PySastrawi/

[34] (2020) Sastrawi Github website [Online] Tersedia: https://github.com/sastrawi/sastrawi/

[35] R. N. Waykole, \& A. D. Thakare. "a Review of Feature Extraction Methods for Text Classification," International Journal of Advance Engineering and Research Development, vol.5(4), pp. 351-354, Apr. 2018.

[36] (2020) FastText website [Online] Tersedia: https://fasttext.cc/docs/en/faqs.html/

[37] P. Bojanowski, E. Grave, A. Joulin, \& T. Mikolov, "Enriching Word Vectors with Subword Information," 2016; arXiv:1607.04606.

[38] S. Raschka, "Model Evaluation, Model Selection, and Algorithm Selection in Machine Learning," 2018; arXiv:1811.12808.

[39] M. S. Santos, J. P. Soares, P. H. Abreu, H. Araujo, \& J. Santos, "Cross-Validation for Imbalanced Datasets: Avoiding Overoptimistic and Overfitting Approaches," IEEE Computational Intelligence Magazine, vol.13(4), pp.59-76. Nov. 2018.

[40] N. V. Chawla, K. W. Bowyer, L. O. Hall, \& W. P. Kegelmeyer, "Smote: synthetic minority over-sampling technique," Journal of artificial intelligence research, vol.16, pp.321-357. Jun. 2002.

[41] M. Bekkar, \& T. A. Alitouche, "Imbalanced Data Learning Approaches Review," IJDKP International Journal of Data Mining \& Knowledge Management Process, vol.3(4), pp.15-33, Jul. 2013. 